\title{
Antenatal Diagnosis of Isolated Total Arhinia in the Second Trimester of Pregnancy
}

\author{
D. Leroy*, E. Slachmuylder, M. Popijn, M. Cassart, A. Massez, N. D'Haene, J. Désir, \\ A. Vandermaelen, C. Daelemans, G. Ceysens, C. Donner \\ Erasme (Fetal Medicine), Brussels, Belgium \\ Email: *delphine.leroy82@gmail.com
}

Received 19 April 2016; accepted 13 June 2016; published 16 June 2016

Copyright (C) 2016 by authors and Scientific Research Publishing Inc. This work is licensed under the Creative Commons Attribution International License (CC BY). http://creativecommons.org/licenses/by/4.0/

(c) (i) Open Access

\begin{abstract}
Congenital arhinia is a very rare condition especially when it is isolated. Most of arhinia are identified after birth and only five prenatal cases are described in the literature. Generally, arhinia is associated with other malformations mainly craniofacial anomalies. Genetics aberrations are uncommon. Our case was diagnosed in the second trimester of pregnancy and we found no associated anomaly except for a single umbilical artery. Autopsy confirmed the diagnosis and neuropathology analysis revealed the absence of olfactory bulbs and tracts.
\end{abstract}

\section{Keywords}

Antenatal, Ultrasound, Arhinia, Diagnosis, Pregnancy

\section{Introduction}

Complete arhinia is defined as the congenital absence of the nose. In the majority of cases, arhinia is associated with other craniofacial anomalies. Isolated arhinia is a very rare condition only reported antenatally in five cases. The majority of cases are sporadic.

\section{Case Report}

A 30 -years-old primigravida was referred at 23 weeks' gestation for a suspected facial anomaly. Her medical and familial histories were unremarkable. A first trimester sonography performed at 13 weeks' gestation showed a

\footnotetext{
*Corresponding author.

How to cite this paper: Leroy, D., Slachmuylder, E., Popijn, M., Cassart, M., Massez, A., D'Haene, N., Désir, J., Vandermaelen, A., Daelemans, C., Ceysens, G. and Donner, C. (2016) Antenatal Diagnosis of Isolated Total Arhinia in the Second Trimester of Pregnancy. Open Journal of Obstetrics and Gynecology, 6, 419-423. http://dx.doi.org/10.4236/ojog.2016.67055
} 
normal nuchal translucency but the nasal bone was not visualized. A second ultrasound performed at 16 weeks was reported normal but the fetal profile could not be obtained. The anatomy scan at 23 weeks' gestation detected the absence of the nose (Figure 1 and Figure 2). This anomaly was documented using 2D and 3D imaging. The profile was flat and the upper lip appeared prominent. No other malformation was detected and the intracranial structures appeared normal. The only associated feature was a single umbilical artery. An amniocentesis was performed and showed a normal karyotype 46XX and a normal CGH array (Agilent $60 \mathrm{~K}$ ).

After receiving extensive information about the possible management of that condition from a genetician, a paediatrician and a paediatric surgeon, the couple opted for termination of pregnancy. The delivery was induced one week later.

After termination, the macroscopic examination confirmed the arhinia (Figure 3 ) and no additional malformations were observed.

The autopsy confirmed arhinia with absence of nostrils, moderate exophtalmy, a small oral orifice and a single umbilical artery. No other fetal abnormalities were identified and placental examination was unremarkable.

Examination of the brain, although not completely contributive because of partial autolysis showed an absence of olfactive bulbs and tracts.

The post mortem CT scan (Figure 4) confirmed the absence of the nasal bone and also showed cribriform plate aplasia and absence of ethmoid sinuses and cells.

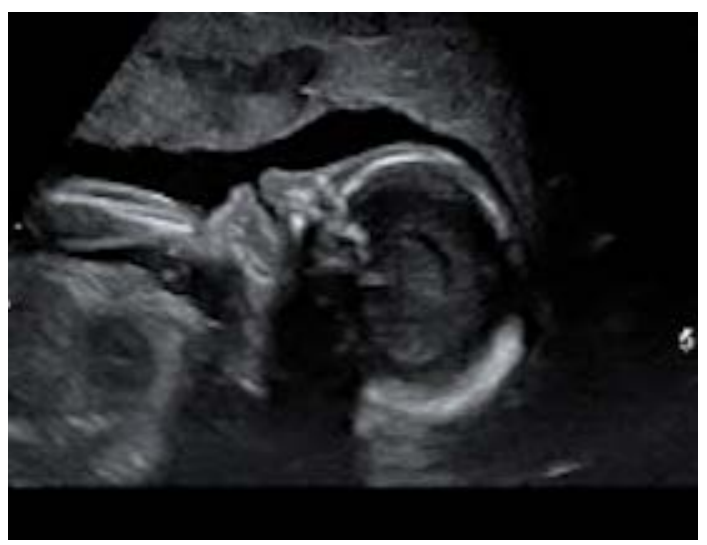

Figure 1.23 wks, sagittal view, absence of nose, prominent upper lip.

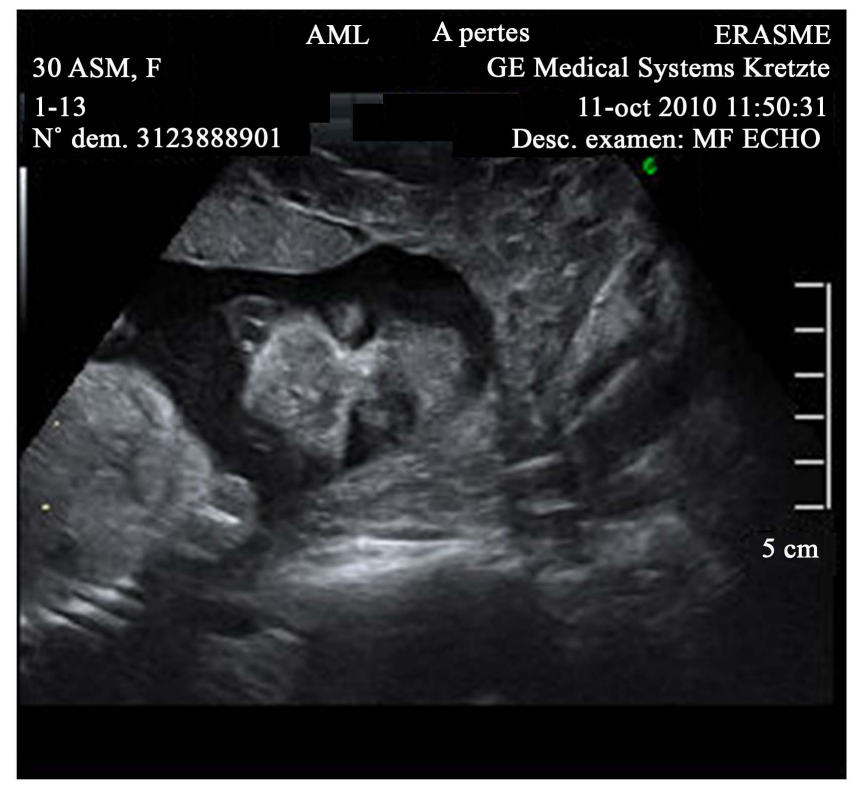

Figure 2. 23 wks, 3D view, absence of nose. 


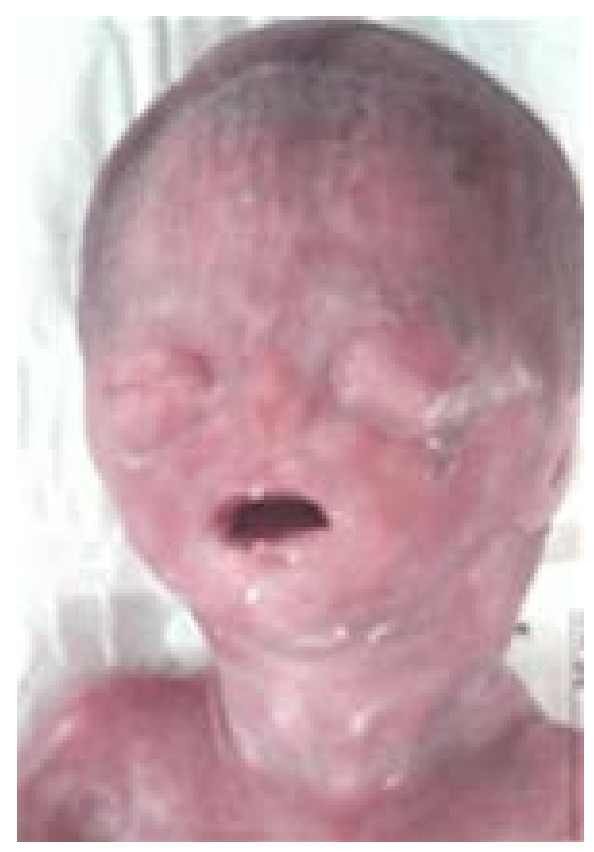

Figure 3. Confirmation of arhinia after termination.

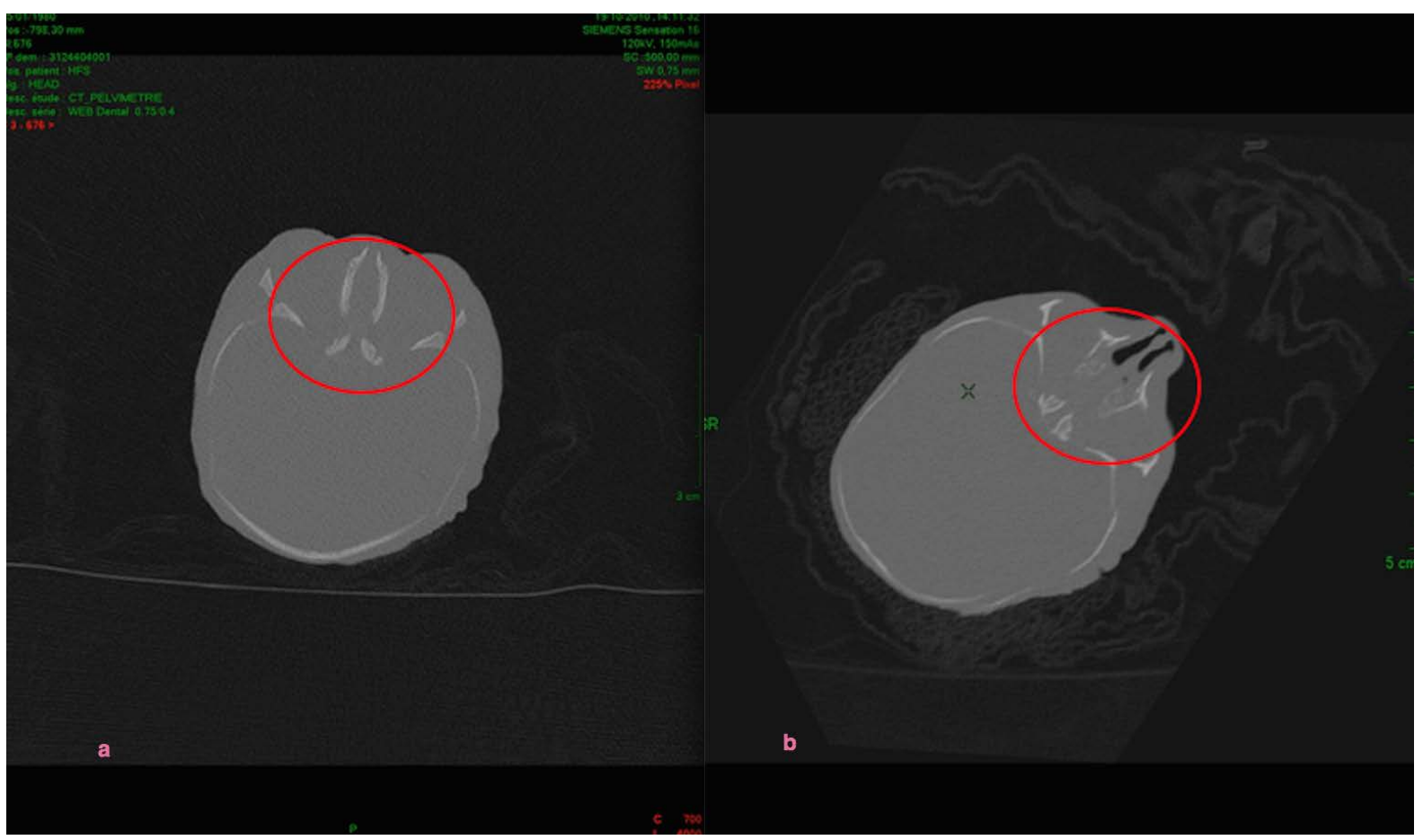

Figure 4. Postnatal CTscan, transverse view (a) our case: absence of nasal and ethmoid bones (b) normal anatomy for comparison.

\section{Discussion}

Complete arhinia is a rare anomaly of unknown origin. Embryologically, the nose develops between the third and the tenth week of pregnancy. Several mechanisms have been suggested to explain this condition: abnormal development of the nasal placodes, lack of resorption of the epithelial nasal bud or abnormal migration of the neural crest cells. Isolated arhinia is a very rare condition described in the literature in 29 neonatal [1] and 5 
prenatal [1]-[4] cases.

Although the majority of cases are sporadic, two familial cases were described with a possible autosomal recessive mode of inheritance in one and autosomal dominant in the second [5] [6]. The chromosomal analysis in patients with arhinia showed normal results, excepting for 3 cases that had an abnormal karyotype: mos46, $\mathrm{XX} / 47, \mathrm{XX},+9$ [7]; 46, XY, inv(9) [8]; 46, XX, t(3;12) (q13.2; p11.2) (de novo) [9]. The third patient was also discovered to be the carrier of a $19 \mathrm{Mb}$ deletion spanning from $3 \mathrm{q} 11.2$ to $3 \mathrm{q} 13.31$ at the $3 \mathrm{q}$ breakpoint of the translocation [10]. As the deleted segment at $3 q$ was a strong candidate region for a putative arhinia gene, array CGH was performed in other arhinia patients, as well as mutation analysis of candidate genes [10]. No consistent gene mutations have been discovered so far; therefore, genetic testing for a putative arhinia gene is not yet available.

In a review of 27 neonatal cases no sex predominance was found. Associated maternal diabetes was suggested in 3 cases [11].

The antenatal diagnosis of arhinia is more often associated with other anomalies of the skull, the face and the brain (abnormalities of the lips and palate, maxillary hypoplasia, microphtalmia, hypertelorism, coloboma, choanal atresia, absence or occlusion of the lacrymal ducts, holoprosencephaly, encephalocele, absence of the olfactory bulbs and tracts).

Some authors have identified cases of arhinia with hypogonadotropic hypogonadism, but no genetic loci were found to explain this association [12]-[14].

To our knowledge, only 5 cases of complete isolated arhinia diagnosed antenatally have been described in the literature, respectively at 23, 25, 27 and 29 weeks [1]-[4] [15]. In our case the diagnosis was also only made at 23 weeks. In the case of Majewski [1], the patient had an ultrasound at 18 weeks where the fetal position did not allow the adequate visualization of the fetal face and the cardiac outflow tracts. A second ultrasound was offered at 22 weeks and the anomaly was then diagnosed. In the case by Olsen [3], the patient had an ultrasound at 17 weeks reporting diffuse midfacial anomalies with edema. The absence of the external nose was diagnosed at 25 weeks. In the case by Thornburg [4], the diagnosis was made during the first ultrasound performed at 27 weeks. In the case by Cusik [2], a first ultrasound was made at 18 weeks but the fetal face and profile could not be visualized due to fetal position. It is the second scan at 29 weeks indicated by gestational diabetes that made the diagnosis possible.

In our case, the patient had ultrasounds at 13 and 16 weeks but the diagnosis was only made at 23 weeks. At the 13 andt 16 weeks ultrasound the face was not adequately visualized as in two other cases [1] [2].

On the other hand, in several cases of isolated arhinia diagnosed at birth, the authors noted that antenatal ultrasound were reported as normal even in one case where an amniocentesis was performed for a positive second trimester triple test [11].

The missed diagnosis is probably due to the rarity of the malformation and the fact that the lack of additional anomalies makes it more difficult to detect it in early pregnancy and in situations where the fetal visualization is not optimal.

A systematic approach during first trimester scan, could help for the earlier diagnosis of arhinia. The use of transvaginal ultrasound when images are suboptimal transabdominally should also be promoted. The 3D ultrasound scanning can also help to demonstrate the absence of nose (Figure 2).

When the diagnosis of arhinia is established, it is important to exclude other facial, skeletal and cerebral anomalies or extra-cerebral malformations. The amniocentesis or chorionic villus sampling is useful to exclude chromosomal abnormalities.

In several studies, the prevalence of fetal abnormalities associated with single umbilical artery is $33.6 \%$ [14]. Interestingly, this particularity was present in our case and in the case by Olsen and al., because of the very small number of cases and the non specific character of a single umbilical artery, we believe this is more of an anecdotical finding than an associated sign.

\section{Conclusion}

Isolated arhinia is a very rare condition. A detailed ultrasound must exclude other anomalies and an invasive sampling could be proposed to detect some genetic aberrations. A systematic approach during first trimester scan (sagittal, horizontal or coronal view of the face) could help for the earlier diagnosis of arhinia. The parents would have more time to receive information and consider their options on the management of this severe condition. 


\section{References}

[1] Majewski, S., Donnenfeld, A.E., Kuhlman, K. and Patel, A. (2007) Second-Trimester Prenatal Diagnosis of Total Arhinia. Journal of Ultrasound in Medicine, 26, 391-395.

[2] Cusik, W., Sullivan, C.A., Rojas, B., Poole, A.E. and Poole, D.A. (2000) Prenatal Diagnosis of Total Arhinia. Ultrasound in Obstetrics \& Gynecology, 15, 259-261. http://dx.doi.org/10.1046/j.1469-0705.2000.00081.x

[3] Olsen, Ø.E., Gjelland, K., Reigstad, H. and Rosendahl, K. (2001) Congenital Absence of the Nose: A Case Report and Literature Review. Pediatric Radiology, 31, 225-232. http://dx.doi.org/10.1007/s002470000419

[4] Thornburg, L.L., Christensen, N., Laroia, N. and Pressman, E.K. (2009) Prenatal Diagnosis of Total Arhinia Associated with Normal Chromosomal Analysis: A Case Report. The Journal of Reproductive Medicine, 54, 579-582.

[5] Ruprecht, K.W. and Majewski, F. (1978) Familiary Arhinia Combined with Peters'Anomaly and Maxilliar Deformities: A New Malformation Syndrome (Author's Transl). Klin Monbl Augenheilkd, 172, 708-715.

[6] Thiele, H., Musil, A., Nagel, F. and Majewski, F. (1996) Familial Arhinia, Choanal Atresia, and Microphthalmia. American Journal of Medical Genetics, 63, 310-313. http://dx.doi.org/10.1002/(SICI)1096-8628(19960503)63:1<310::AID-AJMG51>3.0.CO;2-N

[7] Kaminker, C.P., Dain, L., Lamas, M.A. and Sanchez, J.M. (1985) Mosaic Trisomy 9 Syndrome with Unusual Phenotype. American Journal of Medical Genetics, 22, 237-241. http://dx.doi.org/10.1002/ajmg.1320220204

[8] Cohen, D. and Goitein, K.J. (1987) Arhinia Revisited. Rhinology, 25, 237-244.

[9] Hou, J.W. (2004) Congenital Arhinia with de Novo Reciprocal Translocation t(3;12)(q13.2;p11.2). American Journal of Medical Genetics A, 130A, 200-203. http://dx.doi.org/10.1002/ajmg.a.30268

[10] Sato, D., et al. (2007) Congenital Arhinia: Molecular-Genetic Analysis of Five Patients. American Journal of Medical Genetics A, 143A, 546-552. http://dx.doi.org/10.1002/ajmg.a.31613

[11] McGlone, L. (2003) Congenital Arhinia. Journal of Paediatrics and Child Health, 39, 474. http://dx.doi.org/10.1046/j.1440-1754.2003.00193.x

[12] Tryggestad, J.B., Li, S.B. and Chernausek, S.D. (2013) Hypogonadotropic Hypogonadism Presenting with Arhinia: A Case Report. Journal of Medical Case Reports, 7, 52. http://dx.doi.org/10.1186/1752-1947-7-52

[13] Graham Jr., J.M. and Lee, J. (2006) Bosma Arhinia Microphthalmia Syndrome. American Journal of Medical Genetics A, 140, 189-193. http://dx.doi.org/10.1002/ajmg.a.31039

[14] De Figueiredo, D., Dagklis, T., Zidere, V. and Allan, L. (2010) Nicolaides KH. Isolated Single Umbilical Artery. Ultrasound in Obstetrics \& Gynecology, 36, 553-555. http://dx.doi.org/10.1002/uog.7711

[15] Li, X., Zhang, L. and Wang, F. (2015) Prenatal Diagnosis of Total Arhinia by RMN. Japanese Journal of Radiology, 33, 672-674. http://dx.doi.org/10.1007/s11604-015-0473-7

\section{Submit or recommend next manuscript to SCIRP and we will provide best service for you:}

Accepting pre-submission inquiries through Email, Facebook, Linkedin, Twitter, etc

A wide selection of journals (inclusive of 9 subjects, more than 200 journals)

Providing a 24-hour high-quality service

User-friendly online submission system

Fair and swift peer-review system

Efficient typesetting and proofreading procedure

Display of the result of downloads and visits, as well as the number of cited articles

Maximum dissemination of your research work

Submit your manuscript at: http://papersubmission.scirp.org/ 